\title{
Development of Aceh iron sand to produce pig iron: studies on hardness properties
}

\author{
Sayuti, $\mathrm{M}^{1, *}$, Akhyar Ibrahim ${ }^{2}$, Muhammad Yusuf $^{3}$ and Reza Putra ${ }^{3}$ \\ ${ }^{1}$ Department of Industrial Engineering, Faculty of Engineering Universitas Malikussaleh, 24351 Aceh \\ Indonesia. \\ ${ }^{2}$ Department of Mechanical Engineering, Lhokseumawe State Polytechnics, 24351 Aceh, \\ Indonesia. \\ ${ }^{3}$ Department of Mechanical Engineering, Faculty of Engineering Universitas Malikussaleh, 24351 \\ Aceh Indonesia.
}

\begin{abstract}
Aceh is one of provinces in Indonesia that produces iron sand. However, Aceh iron sand has been sent to other countries in the raw form instead of the processed one, which actually can add significant economic value to the minerals and eventually can contribute to the increased Aceh's PAD (Regional Own-source Revenue) as well as support national industry. A study has been carried out to develop of Banda Aceh iron sand to produce pig iron using reduction processes. Hardness tests and characterization of mineral were performed and the results are reported. The results show that the average hardness properties of both the sponge and the pig iron were 282, $22 \mathrm{HV}$ and $377,178 \mathrm{HV}$, respectively. Chemical composition of pig iron is $2,71 \% \mathrm{C}, 2,5 \% \mathrm{Si}, 0,13 \% \mathrm{~S}, 0,12 \% \mathrm{Cr}, 0,54 \% \mathrm{Mn}$, $0,74 \% \mathrm{Ti}, 0,94 \% \mathrm{Al}, 0,2 \% \mathrm{~V}$ and $92 \% \mathrm{Fe}$.
\end{abstract}

\section{Introduction}

The mineral sands mining (known as the iron sand) has long been carried out for the production of raw materials of the cement industries, such as steel and ceramics, in Indonesia. In 1971, PT Aneka Tambang started the attempts to explore the Cilacap iron sand and exported it particularly to Japan as raw materials for the iron smelting process [1]. The Aceh province has a large amount of iron ore, iron sand, gold, copper, molybdenum, and benthonic. Considering this, the government of Aceh places these minerals as one of the Aceh first ranked commodities [2]. Referring to Government Regulation No. 27, 1980 on minerals' classification, iron sand has been categorized as Group B minerals (vital minerals). In Aceh province, the main producers of iron sand include the districts of Great Aceh, West Aceh, South Aceh, Pidie, North Aceh, Bireuen, and Sabang [3]. With 92.3 million tons deposit in the form of either stones or sand in the rivers and estuaries, this iron ore has potential to carry significant economic value [4,5]. The iron sand resources can be seen in the Fig. 1.

\footnotetext{
*Corresponding author: sayuti_m@unimal.ac.id
} 


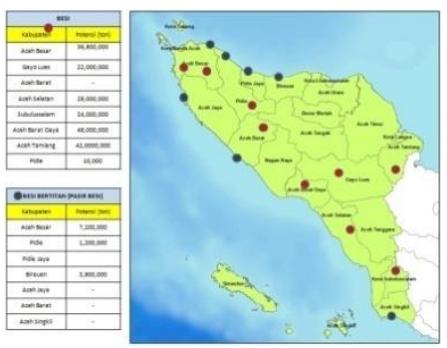

Fig.1. the Aceh iron sand resources and deposit

Today, the major issue regarding the sand products in Aceh is that they are exported to other places without being processed first. The processed products will have significant added value compared to the raw form of iron sand. Furthermore, in Aceh province, iron sand minings are managed by small and medium sized companies where they will export the mineral products to the buyer countries such as China to be processed further and then to be used in steel industries as a raw material in the country. China contributes around $45 \%$ of total world steel production amounting 1.75 million tons in 2015. The steel that is a product of iron sand processing is used as an indicator of the progress of a country.

To have the added value to the products, Aceh's iron sands are ideally should be processed into pig iron and/ or steel and its alloys before they are exported to other countries. There are some processes that can be done including the beneficiation or refining process, pelletizing which enables its use as raw materials in the sponge iron or pig iron making, the reduction process which produces sponge iron and pig iron, and the melting process that produces steel. These products vary in price. The price of iron sand as a mined material is the lowest and the price of the pig iron as a product is the highest $[6,7]$.

Until today, the raw materials for pig iron production process that are derived from the local iron sands have not been used yet. Up to now, the raw materials for the steel industries are still imported from abroad with fluctuating prices. The demand for raw material which is only about $0.2 \%$ of the whole world market of the iron ore has led to the condition where steel industries in Indonesia are not in a good bargaining position where they are able to buy the raw materials at reasonable prices. This situation causes the iron sands industries to obtain the raw material at a very high price. The use of pig iron from iron sand locally causes the raw materials form the national steel industries to become accessable and cheaper. The large amount of the iron reserves made it easier to produce the raw materials that are ready to be used. Moreover, a very short distance between the source of raw materials, the processing place and the steel industries causes the price of pig iron to become lower. This is partly due to the significant factors that affect the price of pig iron such as the delivery cost from overseas (Australia, Brazil or Sweden, etc.), where the minerals are processed, to Indonesia. The purpose of this article is to give the solution for an environmentally friendly process of production of iron sand to Government of Aceh to from the iron sand so that it will have the added value, rather than exporting the iron sand directly without any further production process.

\section{Literature Review}

Studies on iron sand found in Aceh have been conducted but have not been published in any publication on the international level. Some researchers suggest that the dominant mineral ingredient in the iron ore is magnetite $\left(\mathrm{Fe}_{3} \mathrm{O}_{4}\right)$ [8]. Some of them performed a variety of identification and characterization in depth to obtain information related to the 
magnetic properties of $\mathrm{Fe}_{3} \mathrm{O}_{4}[9,10]$, and the latest one is the production of large-scale natural $\mathrm{Fe}_{3} \mathrm{O}_{4}$ nanoparticles for the applications of ferroelectric material [11]. Further applications are the use of $\mathrm{Fe} 3 \mathrm{O} 4$ as a catalyst on a magnesium-based hydrogen storage material and as an anti-corrosion $[6,12]$. The Fe and Ti contained in the iron sand from Aceh are larger than they are in iron sand from Cilacap area and Ujung Pandang, Ti and Fe content ratio ( $\%$ by weight $\mathrm{Ti} / \mathrm{Fe}$ ) is below 0.14 [13, 14]. Zulkarnain [2014] performed phase identification using $\mathrm{X}$-ray diffraction techniques and the result indicates that the iron ore found in Lhoong contain hematite $\left(\mathrm{Fe}_{2} \mathrm{O}_{3}\right)$ up to $93.88 \%$, while those from Manggamat have $85.31 \%$, Lampuuk iron ore has $86.81 \%$ magnetite $\left(\mathrm{Fe}_{3} \mathrm{O}_{4}\right)$ compound, while Babahrot reached $79.22 \%$ [15].

In addition, a study on the identification of metal compound and manufacturing process of the pig iron conversion from iron sand found in Lam Panah in Aceh Besar district and Mon Keulayu in Bireuen district $[16,17]$ has been conducted by Akhyar Ibrahim et al. (2006 and 2012). The results shows that the iron sands from Lam Panah and Mon Keulayu share the dominant compounds, ie hematite $\left(\mathrm{Fe}_{2} \mathrm{O}_{3}\right)$, silica $\left(\mathrm{S}_{\mathrm{i}} \mathrm{O}_{2}\right)$, alumina $\left(\mathrm{Al}_{2} \mathrm{O}_{3}\right)$ and titanium oxide $\left(\mathrm{TiO}_{2}\right)$, while other compounds are minor. Magnetic separation on the sand has successfully extracted the magnetic part and the non-magnetic part which was indicated by the increasing weight of $\mathrm{Fe}$ and $\mathrm{Ti}$ elements whose magnetic properties reached $92 \%$ and the remaining are impurities. Extraction of iron from iron ore concentrate has been successfully carried out by using the method of carbon reduction in a blast furnace. Pig iron has a ferrite microstructure with the graphite respectively $85.8 \%$ and $14.2 \%$. While the analysis of iron sand in Syiah Kuala coast using the X-ray diffraction analysis suggest that the $\mathrm{Fe}_{3} \mathrm{O}_{4}$ (magnetite) phase constitute the majors phase in the iron sand [18].

Iron sand can be used in the steel industry since iron sand contains a lot of iron ( $\mathrm{Fe})$ which is a raw material for steel making. They also contain magnetic minerals such as magnetite $\left(\mathrm{Fe}_{3} \mathrm{O}_{4}\right)$, hematite $\left(\alpha-\mathrm{Fe}_{2} \mathrm{O}_{3}\right)$, and Maghemite $\left(\mathrm{\gamma}-\mathrm{Fe}_{2} \mathrm{O}_{3}\right)$ so that they can be also used in other industries too. Magnetite can be used as a basis for making dry ink / toner that is used in photocopier and laser printer. Maghemit is the raw material in tape manufacturing. The three minerals can also be used in the industrial manufacture of permanent magnets [19]. The products of the raw iron sand processing can be in the form of ingot / steel, titanium, $\mathrm{TiO}_{2}$ pigment, black oxide $\mathrm{Fe}_{3} \mathrm{O}_{4}$ to toner, powder $\mathrm{Al}_{2} \mathrm{O}_{3}, \mathrm{SiO}_{2}$ ceramics, Nano $\mathrm{TiO}_{2}$ and $\mathrm{Fe}_{3} \mathrm{O}_{4}$ for pharmaceutical and medica [6, 20]. Iron sand processing into various products, especially iron / steel, pigments anti-rust paint, and special ceramics can directly support the national program of "The Master Plan for the Acceleration and Expansion of Indonesian Economic Development" (MP3EI) which will require a source of raw materials of iron / steel structures in the construction of roads, bridges, chemical factories, houses, office buildings, transportation equipment and various household products. Meanwhile, a variety of other products such as cosmetics, pharmaceuticals, magnetic, anti-radar coating and the other are also strategic needs to have a relatively high economic value $[6,11]$. By exploiting the iron resources, the added value can be enhanced and can be used to substitute the imported products, and thus, increases the competitiveness of the national industries [21].

The government of Indonesia has issued some regulations regarding the mineral management practice. One of the regulations is Law of the Republic of Indonesia Number 4 Year 2009 on Mineral and Coal Mining, Article 103 paragraph (1) which mentions that those who hold the Production Operation of IUP and IUPK are required to conduct processing and refining of mining production in the country. Another regulation is the government regulation of the Republic of Indonesia Number 23 year 2010 regarding Implementation of Business Activities of Mineral and Coal, Article 112 paragraph (4) c. This regulation states that the processing and refining in the country is conducted within a maximum of five year period starting from the enactment of the No. 4 year 2009 on Law on 
Mineral and Coal Mining (until January 12, 2014).

Seeing the potential and the extended use of the magnetite minerals, and in order to develop the business of non-oil sector, the utilization of iron ore to be processed into halffinished raw materials that are available in Aceh should be taken into account in order to support the national industry.

\section{Processing and Method}

Iron sands can be processed into pig iron using domestic technology and can be done with the capital and the scale of SMEs (UKM), so that it will be in line with the Mining Law no. 4 in 2009 and the Ministery regulation no. 7, 2012 that prohibits all mineral materials in the raw form to be exported as well as with the President of Republic of Indonesia's Instruction No. 3, 2013 regarding the Mineral Added Value Acceleration through Domestic Processing and Refining. The Aceh iron sand can provide added value when processed before it is exported. Some processes that may involve include the beneficiation or refining process, the manufacture of ready to use pellets (palletizing) as raw material in the manufacture of sponge iron or pig iron, the reduction process in which sponge iron and pig iron are produced or smelting process which produces steel products.

The beneficiation process in this research is to take samples of iron sand Aceh Besar districts. The iron sand content is mixed with organic impurities, $\mathrm{Al}_{2} \mathrm{O}_{3}$ (Alumina) and $\mathrm{SiO}_{2}$ (silica) and then separated by using magnetic separator. The result of this separation will be oxide containing ilmenite $\left(\mathrm{FeTiO}_{3}\right)$ up to $50-55 \%$. Then the concentrate iron is fined up to 325 mesh and pelleted (Palletizing) with a mixture of coal, bentonite and lime before it is reduced to a temperature of $1350^{\circ} \mathrm{C}$ to a pig iron product/specimen [23, 24]. Percentage testing of chemical composition of pig iron content is done by using SEM / EDX and the hardness of pig iron was tested by using the Deco Micro hardness Vickers machine. For each sample, five hardness readings were taken randomly from the surface of the samples $[25,26]$. The Flow of processing and method can be seen in the Fig. 2. 


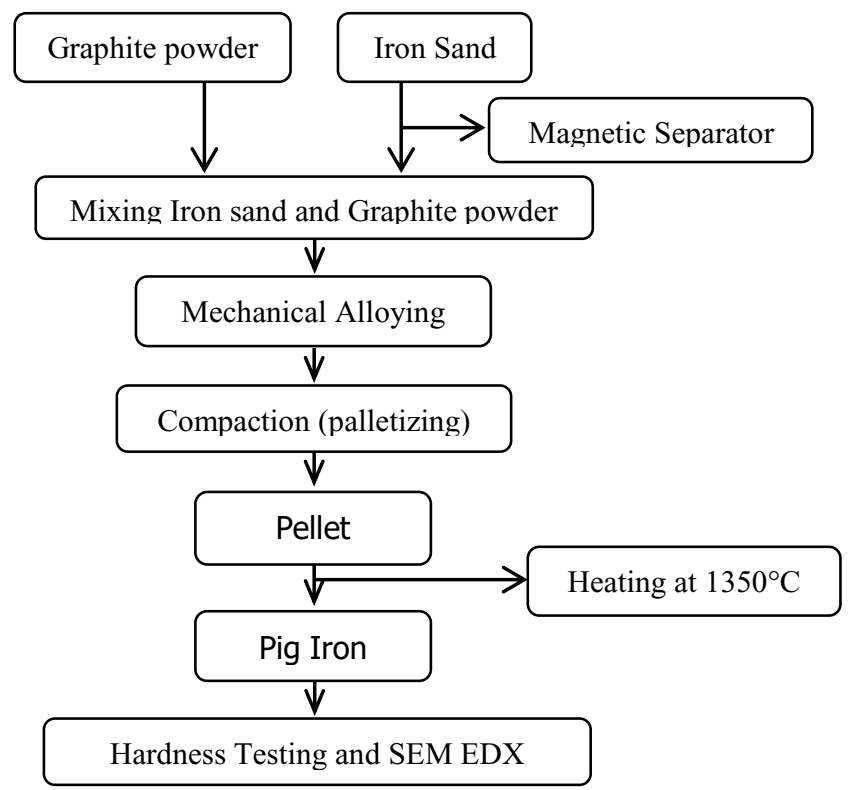

Fig.2. Flow of processing and method

\section{Result and Discussion}

Separation of iron sand from organic impurities, $\mathrm{Al}_{2} \mathrm{O} 3$ and $\mathrm{SiO}_{2}$ with magnetic separator has been done. The result of separation showed that iron oxide concentrate contains ilmenite up to $50-55 \%$ (Figure 3a). The iron concentrate has been fined up to 325 mesh and pellet as shown in Figure $3 \mathrm{~b}$ and the result of iron reduction of sponge and melting into pig iron as Figure $4 \mathrm{a}$ and $4 \mathrm{~b}$.

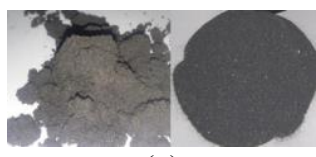

(a)

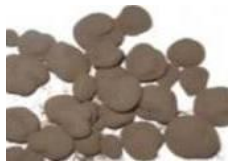

(b)

Fig.3. (a) The iron concentrate sources, (b) Pellet

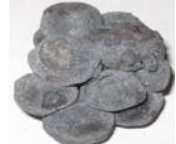

(a)

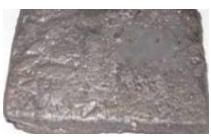

(b)

Fig.4. (a) Sponge Iron, (b) Pig Iron/ingot

The results of the pig iron using Micro hardness Vickers test shown in Table 1. The results show that the tendency of increments that form the linear line. The obvious difference between the inner and outer part of the specimen is due to the process of solidification the molten metal after the melting processes. 
Table1. Hardness properties of Sponge Iron and Pig Iron

\begin{tabular}{|l|c|c|c|c|c|c|}
\hline \multirow{2}{*}{ Materials } & \multicolumn{5}{|c|}{ Hardness value (HV) sample } & Average \\
\cline { 2 - 6 } & 1 & 2 & 3 & 4 & 5 & $(\mathrm{HV})$ \\
\hline Sponge iron & 256.21 & 275.15 & 285.45 & 295.13 & 299.17 & 282.22 \\
\hline Pig iron & 355.18 & 360.11 & 373.23 & 390.26 & 407.11 & 377.178 \\
\hline
\end{tabular}

The average hardness properties of both the sponge and the pig iron were 282, $22 \mathrm{HV}$ and $377,178 \mathrm{HV}$, respectively. Based on the Vickers hardness value, according to Vander Voort (1984), it can be converted into tensile stress $\left(\sigma_{\mathrm{u}}\right)$ obtained by $265 \mathrm{MPa}$ and $415 \mathrm{MPa}$ respectively; while the yield stress $\left(\sigma_{\mathrm{ys}}\right)$ is obtained respectively $170 \mathrm{MPa}$ and $300 \mathrm{MPa}$ [22]. The Chemical composition of iron sand using SEM / EDX as shown in Table 2. The $\mathrm{Fe}$ and $\mathrm{Ti}$ contained in the iron sand from Aceh are larger than they are in iron sand from Cilacap area and Ujung Pandang, $\mathrm{Ti}$ and $\mathrm{Fe}$ content ratio (\% by weight $\mathrm{Ti} / \mathrm{Fe}$ ) is below $0.14[13,14]$.

Table 2. Composition of Pig Iron

\begin{tabular}{|c|c|c|c|c|c|c|c|c|c|}
\hline $\begin{array}{c}\text { Chemical } \\
\text { Composition }\end{array}$ & $\mathrm{F} \mathrm{e}$ & $\mathrm{C}$ & $\mathrm{Si}$ & $\mathrm{S}$ & $\mathrm{Cr}$ & $\mathrm{Mn}$ & $\mathrm{Ti}$ & $\mathrm{Al}$ & $\mathrm{V}$ \\
\hline$\%$ & 92 & 2.7 & 2.5 & 0.13 & 0.12 & 0.54 & 0.74 & 0.94 & 0.2 \\
\hline
\end{tabular}

\section{Conclusion}

The content of iron sands found in Aceh Besar contains hematite $\left(\mathrm{Fe}_{2} \mathrm{O}_{3}\right)$, silica $\left(\mathrm{SiO}_{2}\right)$, alumina $\left(\mathrm{Al}_{2} \mathrm{O}_{3}\right)$ and rutile $\left(\mathrm{TiO}_{2}\right)$. The content of $\mathrm{Fe}$ and $\mathrm{Ti}$ in the iron sand from Aceh are much greater compared to those in the iron sand from Cilacap area, as well as Ujung Pandang. Besides, the ratio of the $\mathrm{Ti} / \mathrm{Fe}$ composition is below 0.4. The average hardness properties of both the sponge and the pig iron were 282,22 $\mathrm{HV}$ and 377,178 HV. Tensile stress $\left(\sigma_{\mathrm{u}}\right)$ obtained by $265 \mathrm{MPa}$ and $415 \mathrm{MPa}$ and the yield stress $\left(\sigma_{\mathrm{ys}}\right)$ is obtained respectively $170 \mathrm{MPa}$ and $300 \mathrm{MPa}$. The pig iron has a grade of $2.71 \% \mathrm{C}, 2.5 \% \mathrm{Si}, 0.13 \%$ $\mathrm{S}, 0.12 \% \mathrm{Cr}, 0.54 \% \mathrm{Mn}, 0.74 \% \mathrm{Ti}, 0.94 \% \mathrm{Al}, 0.2 \% \mathrm{~V}$ and the remaining $92 \% \mathrm{Fe}$. The pig iron also has a microstructure of ferrite and graphite mosaics of $85.8 \%$ and $14.2 \%$, respectively. The potential for iron sand Aceh to be processed into iron products is considered important and need to be done optimally and integratedly, so that it will have higher economic value to support the national industry. The by-products (slag) can also be used as the raw materials for the manufacturing of pigments, ceramics, magnets, cosmetics and photocatalyst. However, further studies are still needed to be done to support previous findings. It is expected that the products made from industrial-scale iron sands processing can be realized in the near future.

The authors of this paper expressed their deep gratitude to the Ministry of Research, Technology and Higher Education (Kemenristekdikti) of the Republic of Indonesia for the HIKOM 2018 Grant. We also extend our thanks to LPPM Universitas Malikussaleh and laboratory assistant so that the research works well. 


\section{References}

1. S. R. Budiono, Indonesia, (1992)

2. Dinas Pertambangan dan Energi. Potensi Bahan Galian; Mineral, Batuan dan Energi Aceh. Banda Aceh: Distamben Provinsi Aceh (2011)

3. Badan Koordinasi dan Penanaman Modal Dalam Negeri. Potensi Bahan Galian Industri dan Bangunan Propinsi Daerah Istimewa Aceh. LaporanTahunan BKPMD Aceh (1993)

4. Dinas Pertambangan dan Energi. Potensi Bahan Galian Unggulan. Distamben Provinsi Aceh (2010).

5. Badan Pusat Statistik. Aceh DalamAngka, LaporanTahunan BPS Kabupaten Aceh Selatan (2012)

6. N. T. Rochman, A. Sukarto, E. Mardliyati, A. Haryono, A. K. Rivai, W. A. Adi, A. H. Yuwono, Yuswono, S. Roseno, S. Soepriyanto, L. S. Hutahaean, B. Prawara, R. Ikono, Suryandaru, D. W. Nugroho, T. P. Rahman, Nofrizal. Prosiding Insinas (2012)

7. Pramusanto, F. Tanjung, Koesnadi, D. Muljono, M.A.Satrio and A. Subandi. Proseding Seminar Sehari bidang Logam MMI (2000)

8. A.Yulianto, S. Bijaksana, and W. Loeksmanto, Kontribusi Fisika Indonesia.

9. C. Peters, and R. Thompson, Journal of Magnetism and Magnetic Materials, 183 (1998).

10. Wu, W., He, Q. and C. Jiang, (2008)

11. W. Widanarto, M. R. Sahar, S. K. Ghoshal, R. Arifin, M. S. Rohani, and K. Hamzah, 326 (2013)

12. Z. G. Huang, Z. P. Guo, A. Calka, D. Wexler, C. Lukey, and H. K. Liu, J. Alloys Compd, 422 (2006)

13. Y. Nampira, Prosiding PPI - PDIPTN.Pustek Akselerator dan Proses Bahan -BATAN (2006)

14. N. C. E. Darmayantil, A. Manafl, B. Briyatmoko. Prosiding Seminar Nasional Balian Magnet I Serpong (2000)

15. Z. Jalil, E. N. Sari, Ismail AB and E. Handoko. Applied Physics (2014)

16. A. Ibrahim, I. Yusuf, and Azwar. Laporan Akhir Research Grant PenggalianUnggulan Daerah (2006)

17. A. Ibrahim, I. Yusuf, and Azwar, Majalah Ilmiah Bissotek (PNL) (2012)

18. Z. Jalil, A. Rahwanto, Mustanir, Akhyar, and E. Handoko. AIP Conf. Proc. (2016)

19. A. Yulianto, S. Bijaksana, and W. Loeksmanto, Jurnal Fisika (2002)

20. C. Ansori. Teknologi Mineral dan Batubara (2003)

21. R. Subagja. Seminar Lokakarya Pemanfaatan Bahan Baku Lokal untuk Industri Baja Nasional (2005)

22. Vander Voort Metallography: Principles and Practice, Material Science and Engineering Series, McGraw-Hill Book Company, New York and Toronto (1984)

23. K. Nagata, R. Kojima, T. Murakami, M. Susa, H. Fukuyama. ISIJ International (2001)

24. B. Anameric, and S. K. Kawatra, Minerals \& Metallurgical Processing (2006).

25. A. Ibrahim and M. Sayuti, Advanced Materials Research (2015)

26. M. Sayuti, S. Suraya, S. Sulaiman, B. T. H. T. Baharudin, M. K. H. Ariffin, And T. R. Vijayaram, AIP Conf. Proc (2010) 